\title{
EFFECT OF GEOPOLYMER ON THE STRENGTH OF BLACK COTTON SOIL
}

\author{
Sachin V Bagewadi ${ }^{1}$, P.G.Rakaraddi ${ }^{2}$ \\ ${ }^{1}$ Post graduate student, Geotechnical engineering, Department of civil engineering, Basaveshwar engineering college, \\ Bagalkot, Karnataka,India. \\ ${ }^{2}$ Professor, Department of civil engineering, Basaveshwar engineering college, Bagalkot, Karnataka,India.
}

\begin{abstract}
This paper presents in the improvement of problematic soils in a environmental friendly method. The present paper geopolymer to stabilize a soft soil. Geopolymer is an alkali activated solution prepared by combining sodium hydroxide(NaOH) with the sodium silicate solution $\left(\mathrm{Na}_{2} \mathrm{SiO}_{3}\right)$. The sodium hydroxide solution is prepared to 12M concentration and Na2SiO3/NaOH ratio of 2.5. The geopolymer increases the strength of the black cotton soil by geopolymerisation. The geopolymerisation process involves three separate but interrelated stages. During initial mixing the alkaline solution dissolves silicon and aluminium ions from the amorphous phases of the feedstock. In this solution, neighboring silicon or aluminium hydroxide molecules then undergo a condensation reaction, where adjacent hydroxyl ions from these near neighbors condense to form an oxygen bond linking the molecules and a free molecule of water. The application of mild heat causes these "monomers" and other silicon and aluminium hydroxide molecules to poly-condense or polymerise, to form rigid chains or nets of oxygen bonded tetrahedra. In the present study geopolymer is treated with the black cotton soil. The effect of geopolymer on strength characteristic of Black cotton soil have been studied for a curing period of 7days 15days and 28days. The compressive strength of black cotton soil increases with geopolymer dosage and curing.. The density of black cotton soil also increases with the increase in geopolymer. The test result indicates that geopolymer is very effective in stabilizing the soft soil. An attempt has been made to study the properties of soil treated with geopolymer
\end{abstract}

Key words : Geopolymer, Black cotton soil, polycondensation reaction.

\section{INTRODUCTION}

Black cotton soil is considered as a problematic soil due to its swelling and shrinking properties when it comes in contact with water. Due to problem of non availability of suitable soil, so many techniques of stabilization are carried on it. Stabilizing with geopolymer is one among them. Geopolymer is a material formed by condensation reaction. In the present paper, investigations were carried out on the compressive strength of black cotton soil at different geopolymer dosage and curing period of 7, 15, 28 days.

\section{MATERIALS USED AND EXPERIMENTAL STUDY}

In the present study black cotton soil is obtained from Kalkeri village Naragunda taluka Gadag District about $100 \mathrm{~km}$ from Bagalkot, Karnataka state, India. Physical properties of black cotton soil is tabulated in table 1 properties of black cotton soil is tabulated in table 1 respectively. Grain size distribution of black cotton soil is as shown in figure 1.
Table 1. Physical Properties of black cotton soil

\begin{tabular}{|c|c|}
\hline Colour & Black \\
\hline Specific gravity & 2.60 \\
\hline $\begin{array}{l}\text { Grain size distribution } \\
\text { Fine sand fraction }(\%) \\
\text { Silt size } \\
\text { Clay size }\end{array}$ & $\begin{array}{l}18.0 \% \\
12.0 \% \\
70.0 \%\end{array}$ \\
\hline $\begin{array}{l}\text { Atterberg's limits } \\
\text { Liquid limit } \quad(\%) \\
\text { Plastic limit } \quad(\%) \\
\text { Shrinkage limit }(\%)\end{array}$ & $\begin{array}{l}76 \% \\
33 \% \\
7.5 \%\end{array}$ \\
\hline $\begin{array}{l}\text { Compaction characteristics: } \\
\text { Maximum dry density }(\mathrm{gm} / \mathrm{cc}) \\
\text { Optimum moisture content }(\%)\end{array}$ & $\begin{array}{l}1.34 \\
33\end{array}$ \\
\hline
\end{tabular}




\begin{tabular}{|l|c|c|c|}
\hline \multicolumn{1}{|c|}{ Combination } & \multicolumn{3}{c|}{$\begin{array}{c}\text { Unconfined } \\
\text { Compressive } \\
\text { Strength (kN/m }\end{array}$} \\
\hline Curing period in days & $\mathbf{7}$ & $\mathbf{1 5}$ & $\mathbf{2 8}$ \\
\hline BCSoil+5\%Geopolymer & 216 & 259 & 324 \\
\hline BCSoil+10\%Geopolymer & 250 & 273 & 341 \\
\hline BCSoil+15\%Geopolymer & 338 & 387 & 398 \\
\hline BCSoil+20\%Geopolymer & 362 & 402 & 513 \\
\hline
\end{tabular}

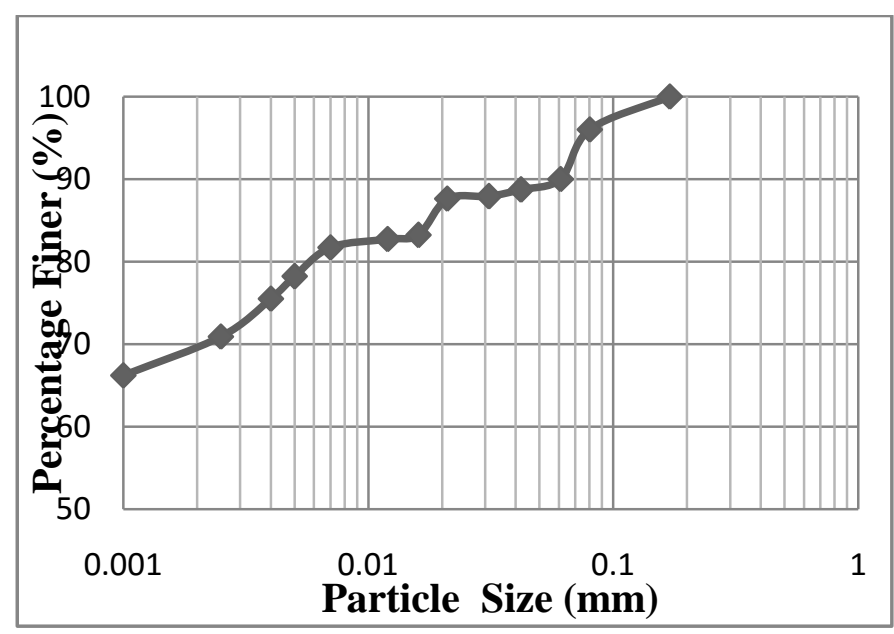

Figure 1. Grain Size Distribution of black cotton soil.

\section{RESULTS AND DISCUSSION}

Experiments are carried out on untreated B.C. soil and treated B.C. soil with curing period of $7,15,28$ days. Table 2 shows the addition of geopolymer in percentage.

Table 2. Experimental programme on unconfined compressive strength for black cotton soil and fly ash mixtures

\begin{tabular}{|l|l|}
\hline Mixture & Curing periods in days \\
\hline $\mathrm{BC}+5 \%$ Geopolymer & \\
$\mathrm{BC}+10 \%$ geopolymer & 7,15 and 28 \\
$\mathrm{BC}+15 \%$ geopolymer & \\
$\mathrm{BC}+20 \%$ Geopolymer & \\
\hline
\end{tabular}

\subsection{Effect of Geopolymer On Black Cotton Soil}

The Black cotton soil was mixed with various percentage of Geopolymer and their strength properties have been studied. From the test results as shown in table 3, Black cotton soil alone have compressive strength of $2.13 \mathrm{~kg} / \mathrm{cm}^{2}$. In addition of geopolymer to Black cotton soil, the compressive strength gets reduces for all dosages of Geopolymer at immediate testing. As the curing period increases compressive strength is also gets increases more than the black cotton soil alone.
Table 3. Unconfined Compressive Strength Of Black Cotton Soil Treated With Various Percentage Of Geopolymer.

From figure 3 to figure 5, graphs are plotted for different percentage dosage of geopolymer cured for 7, 15, 28 days for curing.

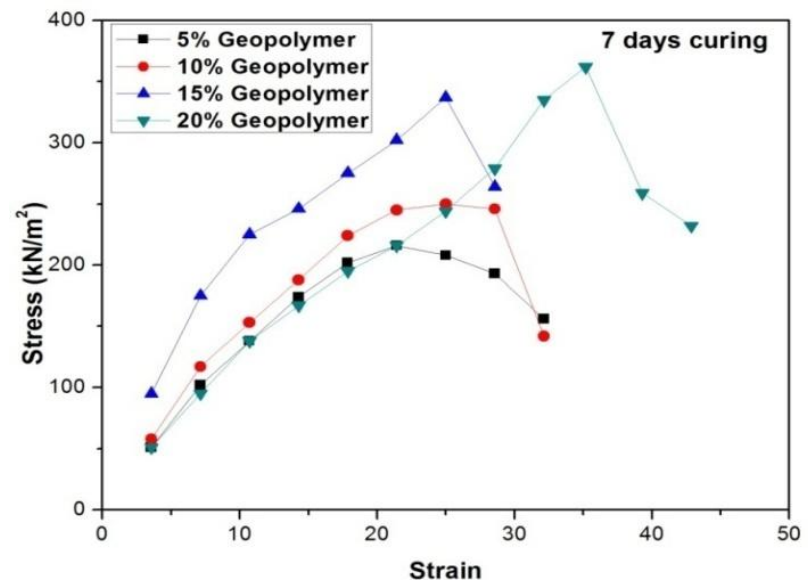

Fig 3. Unconfined compressive strength of black cotton soil treated with various percentage of geopolymer for 7 days of curing.

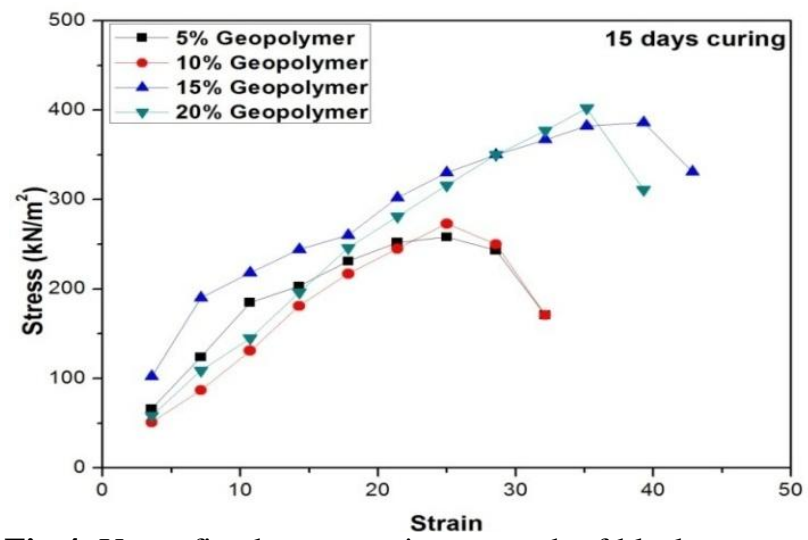

Fig 4. Unconfined compressive strength of black cotton soil treated with various percentage of geopolymer for 15 days of curing.

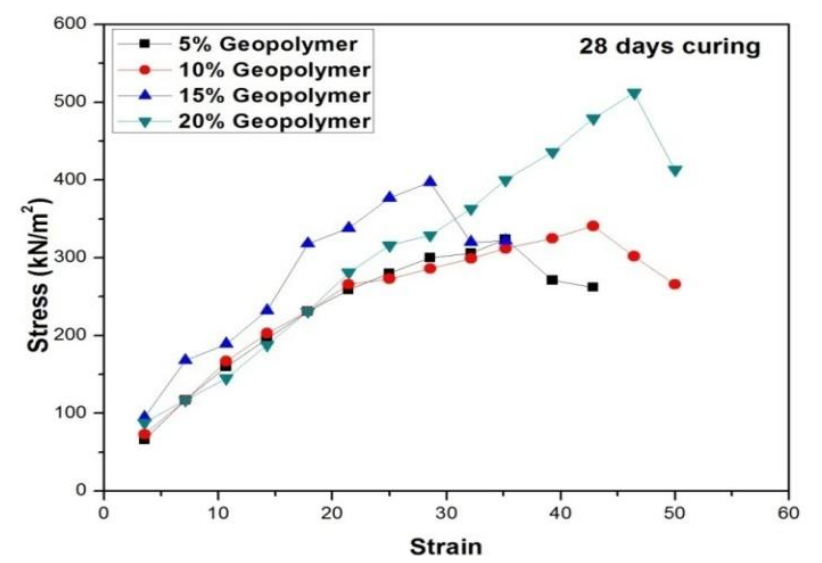

Fig 5. Unconfined compressive strength of black cotton soil treated with various percentage of geopolymer for 15 days of curing. 


\section{CONCLUSION}

The compressive strength increases with the increase in geopolymer. This is because the increases quantity of sodium hydroxide in solution leaches more aluminum and silica from the binder material. Hence this process continues to form a longest rigid network of polymers. So the compressive strength increases with increase in the geopolymer dosage and increase in curing period. From the obtained results we can conclude that, compressive strength of B.C. soil $+20 \%$ of geopolymer gives the highest strength for 28days of curing period as compare to different dosages and for different curing days.

\section{REFERENCES}

[1] AKSHAYA KUMAR SABAT (2012) "A Study on Some Geotechnical Properties of Lime Stabilised Expansive Soil -Quarry Dust Mixes" International Journal of Emerging trends in Engineering and Development Issue 2, Vol.1, page 42-49.

[2] AHNBRG H, JOHNSON S.E (2003), "Stabilizing Effects of different binders in Swedish soils", Ground improvement, 7(1), 9-23.

[3] A.M MUSTAFA AL BAKRI (2011 Microstructure of different $\mathrm{NaOH}$ molarity of fly ash-based green polymeric cement ,jouranal of Engineering and technology Reserch Vol. 3(2), 44-49

[4] BLIGHT. G.E, (1983)," The Behaviour Of Mine Tailings During Hydraulic Deposition" Journal Of The South African Institute Of Mining And Metallurgy Page 73-86

[5] B Fajobi(2012) Engineering properties of acrylic resin on lime stabilized soil, Transnational journal of science and technology $\operatorname{Vol}(2)$ 113-122

[6] D DUTTA(2013) Strength and Durabilitry of Fly ash Geopolymer Blended with lime stone dust,International Journal of Engineering Reserch \&Technology , Vol(2),60-67

[7] DAVIDSON. D.T .AND HANDY (1960), "Improvement of lime stabilization of montmorillonite clay soils with chemical additives", Highway research record, 262, 33-50.

[8] DAFALLA M AND MUTAZ. E (2012) "Study of the Mineralogical Changes of Clay Due to Cement and Lime Addition Using X Ray Diffraction Technique", Research Journal of Applied Sciences, Engineering and Technology 4(19): 3746-3754

[9] D D HIGGINS (2005) soil stabilition with ground granulated blast furnace slag Geotech Geol engg journales 14;212-236

[10]ERDAL COKCA(2009) stabilition of expansive clays using granulated blast furnace slag, Geotech Geol engg journals (GGBS) and GBFS-CEMENT 27,489-499

[11] HAMID BOHLOOLI (2012) Experiment investigation and fuzzy logic modeling of compressive strength of Geopolymer with seeded fly ash and rice husk bark ash ,Elsevier journal, Part B 1293-1301

[12] LAXMIKANT YADU (2013) Stabilition Of Soft Soil With Granulated Blast Furnace Slag And Fly Ash International Journal of Engineering Research \& Technology feb (2013) Vol-(2),115-119
[13] MANOHARA REDDY (1990) Effect of fly ash on black cotton soiland reported that addition of fly ash Journal of Engineering Research Vol. 5(2), 122-131 